\title{
ЕВОЛЮЦІЯ НАУКОВИХ ПОГЛЯДІВ ТА СУЧАСНИЙ СТАН ДОСЛЦДЖЕННЯ ПРОБЛЕМ ПОТЕРПЛЛОО ВІД КРИМІНАЛЬНОГО ПРАВОПОРУШЕННЯ В ДОКТРИНІ КРИМІНАЛЬНОГО ПРАВА
}

\author{
ЛАДАНІВСЬКА Наталія - Донецький юридичний інститут МВС України \\ здобувачка кафедри кримінально-правових дисциплін \\ ORSID. org/0000-0002-8517-2842 \\ УДК 343.2:211.3 \\ DOI 10.32782/EP.2021.20
}

\begin{abstract}
У статті автор приділяе увагу розгляду еволючї вчення про потерпілого від кримінального правопорушення. Вказується, що жертва кримінального правопорушення починала вивчатисъ з віктимологічної точки зору, як біофізичний, психологічний об'єкт, котрий зазнає протиправний вплив. Звертається увага, шо сучасні вчені не завжди бачать людину як центр матеріального та прочесуального права, не приділяють йй увагу як носію прав та свобод, закріплених на конституиійному рівні. Потерпілий розглядається як причина, яка підштовхнула кримінального правопорушника вчинити суспільно небезпечне діяння. Підсумовується, що більшість наук кримінально-правового изиклу обертається навколо суб'єкта кримінального правопорушення та самого правопорушення. Для вчених важливою $є$ першопричина протиправного акту, котра вбачається в особі, яка від нъого постраждала. Саме тому кримінальне право иікавиться жертвою не в повній мірі, віддаючи цей беномен тотожним доктринам.

Ключові слова: потерпілий, кримінальне правопорушення, кримінальне законодавство, віктимологія, кримінальне право, кримінологія, кримінальний правопорушник, проступок, злочин.
\end{abstract}

Сучасне кримінальне законодавство майже досконалий продукт, сформований та отриманий шляхом тривалих наукових пошуків, практичних надбань та роботи законотворців. Не є таємницею, що найбільш впливовою рушійною силою завжди була i залишається наука, адже саме вона забезпечує розвиток суспільства та держави в цілому. Кримінальне право не виняток 3 вищевказаної тези. На сьогодні ми маємо знання майже про всі протиправні феномени, вміємо правильно реагувати на них, захищати права та законні інтереси громадян України. При цьому, незважаючи на такий стан справ, на жаль, і у XXI столітті існують невирішені проблеми та прогалини, однією з таких прогалин є відсутність сталого та виваженого підходу до особи потерпілого від кримінального правопорушення. Звичайно, не можна стверджувати, що кримінально-правова доктрина не має відповідних досліджень, однак усі вони відповідають лише на окремі питання, котрі не в повній мірі заповнюють існуючу ланку. Саме в цьому контексті видається цінним та актуальним провести огляд еволюції наукових поглядів та сучасного стану дослідження проблем потерпілого від кримінального правопорушення в доктрині кримінального права.

Відтак, «безпосередньо проблема потерпілого від злочину в кримінальному праві має глибокі історичні корені, які відходять у часи становлення цієї галузі знання. На деякі аспекти проблеми звертав увагу щеЧ. Беккаріа у праці «Про злочини та покарання». Усвідомлюючи значущість потерпілого для з'ясування суті злочинів, саме його ознаку Ч. Беккаріа поклав в основу класифікації злочинів, у якій на перше місце поставив злочини, що заподіюють шкоду суспільству або тому, хто його уособлює, а на друге 
- злочини проти людини» [1, с. 27]. «Згодом ця класифікація знайшла відображення у французькому кримінальному законодавстві. Величезний внесок у дослідження проблеми потерпілого зробили представники класичної школи кримінального права. Виходячи з філософської доктрини про повну незалежність акту волі від будь-яких факторів, вони розглядали злочинність не як соціальне, а як суто юридичне явище, не пов'язане з існуючими в суспільстві відносинами. Саме 3 формальних позицій до визначень кримінально караного діяння представники класичної школи кримінального права підійшли до досліджень питань потерпілого від злочину. Так, А. Фейєрбах розглядав потерпілого як обов'язкову ознаку будь-якого злочину: «Кожне діяння, яке визначається як злочин, містить у собі: поперше, зовнішню ознаку; по-друге, відсутність правомірної підстави, яка б могла спонукати людину до такого діяння; по-третє, особу як предмет (object) порушеного права, бо злочин може бути вчинений тільки проти особи, яка перебуває під захистом Уряду, котрий вважає кримінальний закон порушеним» [2, с. 31-32]. «В. Спасович в одному 3 перших російських підручників 3 кримінального права, розглядав потерпілого як предмет (об'єкт) злочину» [3, с. 91, 94]. Що стосується тези А. Фейербаха, то, безперечно, людина - один із основних елементів, необхідних для існування суспільно небезпечного діяння в його матеріальному розумінні. Варто зазначити, що наразі думка про те, що потерпілим від кримінального правопорушення може бути тільки людина, піддається серйозній критиці, що викликає жваві дискусії. Що стосується думки В. Спасовича, то, звичайно, сучасне кримінальне право не може розглядати людину як об'єкт кримінального правопорушення.

Свого часу питанням особи потерпілого приділив комплексну увагу і О. Лохвицький. У главі X «Обстановка злочину» підручника 3 кримінального права, характеризуючи потерпілого, він зазначав, що «стосовно особи як об'єкта злочину нашому законодавству відомо багато сторін: вік, стать, стан розуму, фізичні вади, політичне становище, шлюбні та родинні стосунки» [1, с. 28]. «Виходячи 3 цього, О. Аохвицький проводив класифікацію тих потерпілих, які є ознаками складів злочинів» [4, с. 200]. «Поняття потерпілого від злочину розробляв М. Таганцев [5, с. 21]. Він також торкався питань згоди потерпілого на заподіяння шкоди та його примирення $з$ винним» [1, с. 28]. «Антропологічна школа практично повністю відкинула формально-правові інститути кримінального права, зокрема, вчення про юридичний характер злочину, і всю увагу сконцентрувала на злочинцеві, його особистості. Антропологи так різко розвернулися від злочинного діяння до його діяча, що практично повністю з поля зору іншого суб'єкта, який виникає у разі вчинення злочину, а саме потерпілого. Виняток з правила становлять лише деякі аспекти творчості Е. Феррі, який у праці «Кримінальна соціологія» питання потерпілого розглядав як частину проблеми покарання злочинця та відшкодування збитків, заподіяних злочином» [6, с. 527]. На нашу думку, таке своєрідне ставлення до потерпілої особи у ХX столітті можна пояснити майже повною відсутністю знань про істинну природу протиправного діяння, його механізм тощо. Тогочасне кримінальне право було дещо відокремленою наукою та ще не в повну силу співпрацювало із кримінологією, а про віктимологію в ії сучасному розумінні мова взагалі не велася. Саме тому, вивчаючи антипод правопорушника, вчені бачили його саме в контексті самого правопорушення, не акцентували увагу на порушенні/посяганні на права особи, а враховували лише зовнішню оболонку фізичної особи, котрій певним чином спричинили шкоду.

«Безпосередньо ж вчення про жертву (потерпілого) від злочину (віктимологія) як самостійний науковий напрямок у кримінології з явилось у 40-х рр. ХХ ст. $з$ публікацією робіт Ганса фон Гентінга та Бенджаміна Мендельсона, які заклали основи віктимології, визначили ії предмет, методи дослідження і розробили відповідну термінологію. У 1947 році, виступаючи на конференції психіатрів у Бухаресті з докладом «Нові психосоціальні горизонти: віктимологія», Б. Мендельсон вперше застосував термін «віктимологія». Пізніше в праці «Нова галузь біопсихосоціальної науки - віктимологія» 
були визначені основні теоретичні положення віктимології: розкрито понятійний апарат; виділено окремі групи жертв; вперше дано поняття «кримінальна пара», «добровільна жертва», «кандидат у жертви», «жертва-провокатор», «жертва-агресор», «індекс жертвеності». Утворення віктимології, як наукового напрямку в середині XX ст., обумовлено наявністю обставин, які сприяють виникненню цього знання на певному етапі історичного розвитку: досягнення необхідного рівня розвитку базових наук; наявності соціального замовлення на розвиток знань, які представлені новим науковим напрямком» [7, с. 119]. Знову-таки, що ми бачимо? Жертва кримінального правопорушення починає вивчатись із віктимологічної точки зору, як біофізичний, психологічний об'єкт, котрий зазнає протиправний вплив. Учені не бачать людину як центр матеріального та процесуального права, не приділяють їй увагу як носію прав та свобод, закріплених на конституційному рівні. Потерпілий розглядається як причина, яка підштовхнула кримінального правопорушника вчинити суспільно небезпечне діяння. Тобто більшість наук кримінально-правового циклу обертається навколо суб'єкта кримінального правопорушення та самого правопорушення. Вчені не цікавляться наслідками протиправного акту, для них важливою $е$ першопричина, котра вбачається в особі, яка від нього постраждала.

Отже, ми можемо підсумувати, що спочатку еволюція наукових поглядів на потерпілого від кримінального правопорушення мала місце лише у кримінології, віктимології та лише в окремих випадках - у межах кримінального права. Сучасні вчені все більше розуміють цінність знання про жертву кримінального правопорушення та починають вивчати її як у загальному розумінні, так і в контексті окремих протиправних діянь. Так, наприклад, E. Черніков розглядає потерпілого в межах наукової статті на тему: «Потерпілий як ознака складу злочину, передбаченого статтею 140 кримінального кодексу України (невиконання або неналежне виконання професійних обов'язків медичним або фармацевтичним працівником)», у якій вказує, що «у структурі об’єкта зло- чину потерпілий є суб'єктом (учасником) охоронюваного законом суспільного відношення, благу, праву чи інтересу якого злочином заподіюється шкода або створюється загроза такої. Водночас у низці наукових досліджень поняття потерпілого ототожнюють із поняттям предмета злочину як факультативні ознаки об'єкта злочину. Ця теорія нівелює значення людини, її життя та здоров’я як найбільшу цінність, що перебуває під охороною закону. Фактично таке ототожнення означає пропозицію відмовитись від концепції першочергової охорони найвищої соціальної цінності. Тривалий час іде дискусія щодо можливості визнання потерпілого (фізичної особи), а також окремих органів, тканин і крові людини предметом злочину» [8, с. 121]. Здебільшого позиція науковця співпадає із нашою, оскільки, як ми вказували вище, дійсно, вважати потерпілого частиною складу кримінального правопорушення - це нівелювати місце людини в правовому вимірі. При цьому сам підхід вченого до виокремлення конкретного виду потерпілої особи в контексті визначеного кримінального правопорушення свідчить про доцільність та актуальність кримінально-правової диференціації жертв суспільно небезпечних діянь.

Продовжуючи свою думку, Є. Черніков вказує, що «з цього приводу існують дві діаметрально протилежні точки зору. Одна 3 них полягає в тому, що людина не може бути предметом злочину; відповідно до іншої - людина може визнаватися предметом злочину. Деякі вчені вважають, що особи, на яких спрямовано злочинний вплив, охоплюються поняттям предмета злочину. Однак при цьому, з метою наголошення на особливому значенні людини як соціальної цінності, а також згідно зі змістом доктрини права людину, стосовно якої здійснено злочинний вплив, у кримінальному праві називають потерпілим, а не предметом злочину. Такої позиції дотримується і М.П. Бікмурзін, який стверджує, що потерпілий у кримінальному праві є різновидом предмета злочину [9]. Інколи у кримінально-правовій літературі можна знайти твердження про те, що предметом злочину є життя та здоров'я людини. Проте така позиція вба- 


\section{Кримінальне право, кримінальний процес та криміналістика}

чається спірною. Життя, здоров'я, честь і гідність особи - це поняття, що в контексті кримінального права розглядаються як нематеріальні утворення; вони належать до предмета суспільних відносин і тому не можуть визнаватися предметами злочину» [10, с. 66]. Ми звичайно, вважаємо, що предмет кримінального правопорушення - поняття більш матеріальне, ніж абстрактне. Сприйняття людини як предмета протиправного діяння дещо ускладнюе прагматичний та практичний підхід до розслідування окремих видів кримінальних правопорушень та може мати наслідком необхідність перегляду норм Загальної та Особливої частини вітчизняного кримінального законодавства.

M.B. Сенаторов проблемі потерпілого посвятив монографічне дослідження на тему: «Потерпілий від злочину в кримінальному праві», у якому вказав, що «ефективне проведення реформи у сфері захисту прав потерпілих від злочинів неможливе без створення надійної наукової бази, без розв'язання загальних віктимологічних проблем, серед яких на перший план виступає поняття потерпілого від злочину. Воно використовується різними науками кримінально-правового циклу, кожна з яких вкладає в нього свій зміст. У їх ієрархії визначальне місце належить саме кримінальному праву, категоріальний апарат якого повинен певним чином відбиватися при формуванні понять в інших науках. Так, стосовно визначення способу вчинення злочину в науках кримінально-правового циклу М. Панов слушно зауважує: «...спосіб вивчається багатьма науками, що досліджують різні аспекти проблеми боротьби зі злочинністю: кримінальним правом, кримінологією, кримінальним процесом, криміналістикою. Визначальне значення серед цих наук має наука кримінального права. Вона є базовою, фундаментальною наукою щодо інших наук кримінального циклу, які в цьому випадку виступають як прикладні науки» [1, с. 18]. Ми абсолютно погоджуємось із вченими. Більше того, ми впевнені, що кримінальне право - це базова доктрина, яка повинна мати власне бачення потерпілого від кримінального правопорушення із його визначеним статусом. Кримінологія, віктимологія, кримінально-виконавче право, кримінальне процесуальне право та криміналістика існують задля забезпечення вдалої та повноцінної реалізації кримінальним законодавством свого основного завдання, котре полягає у захисті прав та свобод людини та громадянина, а тому потерпілий - це екватор сучасного вітчизняного кримінального законодавства.

Отже, «науки кримінального циклу перебувають між собою у відношенні не тільки координації, але й субординації, причому в цьому їх співвідношенні прикладні науки у значній мірі підлеглі науці кримінального права. Це, зокрема, означає, що поняття, розроблювальні в кримінальному праві, акумулюються кримінологією, кримінальним процесом, криміналістикою, асимілюються ними. Поняття кримінального права виступають щодо понять інших суміжних наук як базисні, з яких і повинні виходити ці науки при розробці питань, що випливають із предмета їхнього дослідження. Тому всі науки, що вивчають спосіб вчинення злочину, повинні виходити з одного, загального для всіх них поняття способу, яке розроблюється наукою кримінального права». Отже, орієнтуючись на систему співвідношення наук кримінально-правового циклу, можна зробити висновок, що визначення загального віктимологічного поняття потерпілого від злочину є питанням, що охоплюється сферою науки кримінального права» [1, с. 18].Це - беззаперечна істина. Наразі кримінальне право має ведучу роль, однак повністю ігнорує вчення про потерпілу особу, віддаючи перевагу кримінальному правопорушнику. Такий стан справ, на нашу думку, можна пояснити орієнтацією законодавця на зниження інтенсифікації криміногенних загроз, рівня кримінально-протиправної діяльності тощо. Історичним фактом 6 те, що кримінальне право - наука про кримінальне правопорушення, а тому і основна увага має приділятись його суб'єкту. У сучасних умовах такий підхід є недосконалим.

У 2017 році А.А. Музика в науковій праці: «Потерпілий від злочину має набути у кримінальному праві реального статусу» зазначив, що «праворозуміння кожного із нас слід наповнити усвідомленням того, 
що Кримінальний кодекс України адресований будь-якій людині, котра мешкає (не торкаючись винятків) на території нашої держави. Це означає, що до складу учасників кримінальних правовідносин належать не лише держава і правопорушник (злочинець), а, щонайменше, потерпілий від злочину (у кримінально-правовому сенсі) та юридична особа (у статусі потерпілого за КПК України), якщо такі фігурують у кримінальному провадженні. Однак сьогодні потерпілий від злочину, відповідно до теоретичних положень кримінального права, перебуває за межами кримінально-правових відносин. 3 якого ж тоді дива вони виникають у випадках, коли від злочину безпосередньо чи опосередковано потерпає конкретна людина? Адже, наприклад, усім добре відома ситуація, за якої потенційний підозрюваний ніколи не набуде статусу обвинуваченого і засудженого, якщо у справі про вбивство відсутній труп потерпілого. У свою чергу, цей факт свідчитиме про відсутність події злочину і відповідно - підстави виникнення кримінально-правових відносин. Отже, необхідно докорінно переглянути науковий погляд на кримінальноправові відносини, згідно з яким останні виникають та існують між суб'єктом злочину і державою в особі уповноважених на те державних органів: дізнання, досудового слідства, прокуратури, суду, органів системи виконання кримінальних покарань та їх службових осіб» [11, с. 31]. Наявність різних підходів до феномену потерпілого в науках одного циклу призводить до плутанини на практиці. Уже давно пора сформулювати єдине бачення потерпілого або як фізичної або як фізичної та юридичної особи. Доктрина кримінального права має достатньо багато інструментарію та знань, необхідних для формулювання дочірньої підсистеми, присвяченої розгляду особи, потерпілої від кримінального правопорушення. Якщо у XX столітті такі прогалини були зрозумілі та некритичні, то сучасне законодавство країни, яка претендує на гідне місце на міжнародній арені повинно мати модернізований підхід до справи протидії злочинності у всіх їі проявах та всіма можливими шляхами.
Таким чином, на сьогоднішній день вчення про потерпілого від кримінального правопорушення в кримінальному праві України знаходиться лише на початку свого розвитку. Це можна пояснити тим, що протягом останніх століть людина розглядались лише у ролі кримінального правопорушника або потерпілого, але $з$ точки зору провокуючого кримінальне правопорушення фактору. Саме через це актуальними для доктрини вітчизняного кримінального права залишаються такі проблеми як: 1) визначення універсальної дефініції «потерпілий від кримінального правопорушення»;2) встановлення природи та ознак потерпілого від кримінального правопорушення; 3) встановлення місця потерпілого в складі кримінального правопорушення; 4) визначення місця потерпілого та його статусу у міжнародних та зарубіжних нормативноправових актах; 5) диференціація потерпілих від кримінальних правопорушень у межах кримінального законодавства України. Вирішення вищевказаних проблем зможе надати законодавцеві можливість якісно удосконалити Кримінальний кодекс, поглибити знання практиків про окремі види кримінальних правопорушень та деталізувати місце та роль потерпілого в контексті проступку та злочину.

\section{Мiтература}

1. Сенаторов М. В. Потерпілий від злочину в кримінальному праві / За науковою редакцією доктора юридичних наук, професора, академіка Академії правових наук України В. I. Борисова. Х.: Право, 2006. 208 c.

2. Фейербах А. Уголовное право: Учебник. СПб: Медицинская типография, 1810. $142 \mathrm{c}$.

3. Спасович В. Д. Учебник уголовного права. Вып.1. СПб: Типография Иосафата Огризко, 1863. Т, 1. 442 с.

4. Лохвицкий А. Курс русского уголовного права: Учебник. 2-е испр. и доп. изд., сведенное с кассац. решен. СПб: Скоропечатня Ю. О.Шрейера, 1871. 714 с.

5. Таганцев Н.С. Русское уголовное право. Часть Общая. Тула: Автограф, 2001. T.1. 1488 c. 


\section{Кримінальне право, кримінальний процес та криміналістика}

6. Ферри Э. Уголовная социология: Исследование: Пер. с 5-го франц. изд. 1905 г. М.: Типография В. М. Саблина, 1908. 625 с.

7. Давиденко В.А. Віктимологія як галузь кримінологічної науки. Європейсъкі перспективи. 2014. №8. С. 118-121.

8. Черніков Є. Потерпілий як ознака складу злочину, передбаченого статтею 140 Кримінального кодексу України (невиконання або неналежне виконання професійних обов'язків медичним або фармацевтичним працівником). Вісник Національної академї прокуратури Украӥни. 2015. № 3. С. 119-125.

9. Бикмурзин М.П. Предмет преступления: теоретико-правовой анализ: автореф. дисс. на соискание учен. степени канд. юрид. наук: спец. 12.00.08. «Уголовное право и криминология; уголовно-исполнительное право» / М.П. Бикмурзин. Саратов, 2005. 30 c.

10. Музика А.А. Предмет злочину: теоретичні основи пізнання: моногр. / А.А. Музика, Є.В. Аащук. К., 2011. 192 с.

11. Музика А. А. Потерпілий від злочинумає набути у кримінальному праві реального статусу. Бюлетень міністерства юстииї Украӥни. 2017. №8. С. 29-33.
EVOLUTION OF SCIENTIFIC VIEWS AND THE CURRENT STATE OF STUDY OF PROBLEMS OF THE VICTIM OF CRIMINAL OFFENSE IN THE DOCTRINE OF CRIMINAL LAW

In the article the author pays attention to the origin of the doctrine of the victim of a criminal offense. It is stated that the victim of a criminal offense began to be studied from a victimological point of view, as a biophysical, psychological object that is subject to illegal influence. It is noted that modern scholars do not always see man as the center of substantive and procedural law, do not pay attention to him as a bearer of rights and freedoms enshrined at the constitutional level. The victim is seen as the reason that prompted the criminal offender to commit a socially dangerous act. It is concluded that most of the sciences of the criminal law cycle revolve around the subject of the criminal offense and the offense itself. Scientists are not interested in the consequences of an illegal act, they are interested in the root cause, which is seen in the person who suffered from it. That is why criminal law is not fully interested in the victim, giving this phenomenon to identical doctrines.

Key words: victim, criminal offense, criminal legislation, victimology, criminal law, criminology, criminal offender, misdemeanor, crime. 